\title{
粒子偏平挙動解析による溶射プロセスの制御化
}

\author{
福本昌宏*
}

\section{Controlling of Thermal Spray Process by Means of Analysis on Flat- tening Behavior of Individual Sprayed Particle}

\author{
Masahiro Fukumoto
}

\begin{abstract}
Synopsis
A variety of metallic or ceramic powder particles were thermally sprayed onto the mirror polished metallic substrate surface and the effect of both substrate temperature and ambient pressure on the flattening behavior of the particle was systematically investigated. In the flattening behavior of the sprayed particle onto the substrate surface, critical conditions were recognized both in the substrate temperature and ambient pressure. That is, the flattening behavior changed transitionally from a distorted shape with splash to a disk shape without splash on that critical temperature and pressure range, respectively. The results indicate that instead of the ordinal particle oriented factors, such as particle's velocity and temperature, particle/substrate interface oriented factors like substrate temperature and ambient pressure affect more the flattening behavior of the sprayed particle. A transition temperature, Tt, and transition pressure, Pt, were defined and introduced, respectively for those critical conditions. The fact that the dependence both of transition temperature and transition pressure on the sprayed particle material had similar tendency indicated that the wetting of the substrate by the molten particles seemed to be domination in the flattening. Three dimensional transition curvature by combining both transition temperature and transition pressure dependence was proposed as a practical and effective controlling principle of the thermal spray process.
\end{abstract}

\section{1.はじめに}

プロセス研究の醍醐味は, 主支配因子の特定ならびに影 響解明を通じプロセスの制御化を達成し, 信頼性を確立す ることにある.溶射法においても，所望とする皮膜を自在 に再現よく製作するには, おのずと高い制御性が求められ るが, 現状の溶射技術ではいまだ十分とはいい難い。通 常, 溶射における膜形成過程では, 大きさや形状の異なる 原材料粉末粒子群が分布を有する加熱・加速場中に投入さ れ, その結果, 統計的な分布状態に加熱・加速された粒子 群が, 粗面化された基材または不規則形状の既形成皮膜表 面上に付着積層する.すなわち積層に至る個々の粒子の経 歴はあまりに多種多様であり, 素過程そのものが高次の確 率的現象であるために, 溶射技術の制御化達成に多くの困
難を伴うことは, いわば自明ともいえる。ただし, 溶射法 がミクロンサイズの粒子を膜構成の基本単位とすること から, プロセスの制御化を目指し, 達成に向けた取組を推 進するには, 個々の粒子の飛行, 衝突, 偏平ならびに凝固 現象の詳細な観察, それぞれの事象に関る支配因子の把 握，またそれら因子の影響解明が，あくまで基本となる. 本稿では特に, 基材上における溶射粒子偏平現象の解析 による溶射プロセス制御化への取組の現状を述べる。

\section{2. 材料および実験方法}

研究では基本的に, $10 \sim 44 \mu \mathrm{m}$ の粒度分布を有する市 販の各種金属およびセラミックス粉末を，また溶射には， Metco-9MBガンによる大気プラズマ溶射, およびPlasmadyneSG100 ガンによるチャンバー内不活性雲囲気中での減圧 
Table 1. Spraying conditions.

\begin{tabular}{|c|c|c|}
\hline \multicolumn{3}{|c|}{ Atmospheric plasma spray } \\
\hline \multicolumn{2}{|c|}{ Spray distance (mm) } & 200 \\
\hline \multicolumn{2}{|l|}{ Arc current $(\mathrm{A})$} & 600 \\
\hline \multirow{2}{*}{$\begin{array}{l}\text { Operating gas } \\
\text { flow rate( }(1 / \mathrm{min})\end{array}$} & $1 \mathrm{st}: \mathrm{N}_{2}$ & 70.8 \\
\hline & 2nd: $\mathrm{H}_{2}$ & 4.72 \\
\hline \multicolumn{2}{|l|}{ Arc voltage $(\mathrm{V})$} & 70 \\
\hline \multicolumn{2}{|c|}{ Powder carrier gas; $\operatorname{Ar}(1 / \min )$} & 5.0 \\
\hline \multicolumn{2}{|c|}{ Powder feed rate (g/min) } & 6.0 \\
\hline
\end{tabular}

\begin{tabular}{|c|c|c|}
\hline \multicolumn{3}{|c|}{ Low pressure plasma spray } \\
\hline \multicolumn{2}{|c|}{ Chamber pressure (torr) } & $30-760$ \\
\hline \multicolumn{2}{|c|}{ Spray distance $(\mathrm{mm})$} & $200-300$ \\
\hline \multicolumn{2}{|l|}{ Arc current $(A)$} & 900 \\
\hline \multirow{2}{*}{$\begin{array}{l}\text { Operating gas } \\
\text { flow rate }(1 / \mathrm{min})\end{array}$} & 1st:Ar & 50 \\
\hline & 2nd:He & 12 \\
\hline \multicolumn{2}{|l|}{ Arc voltage $(\mathrm{V})$} & 40 \\
\hline \multicolumn{2}{|c|}{ Powder carrier gas; $\operatorname{Ar}(1 / \min )$} & 5.0 \\
\hline \multicolumn{2}{|c|}{ Powder feed rate $(\mathrm{g} / \mathrm{min})$} & 6.0 \\
\hline
\end{tabular}

プラズマ溶射を用いている.両プラズマ溶射における溶射 条件を Table 1 に示す. 基材には $25 \mathrm{~mm}$ 角 $\times$ 厚さ $5 \mathrm{~mm}$ で, 表面を鏡面研磨したステンレス SUS304 鋼を用いた.トー チ/基材間にスリットおよびエアシリンダーにより駆動す るシャッター装置を設置し, 定常状態の溶射において, ス リット・シャッター越しに飛来した標準的な温度・速度履 歴を有する数十個程度の粒子を, シャッタリングごとに基 材上に捕集した. 得られた個々の偏平粒子について, 光学 顕微鏡またはSEMにより形態の詳細を観察した。なお基 材予熱実験では, 基材をホットプレート上で所定の温度に まで加熱した後，即座に粒子捕集実験に供した。減圧プラ ズマ溶射実験では，チャンバー内をいったん $0.7 \mathrm{kPa}$ にま で減圧した後，作動ガスの Ar をチャージすることで所定 圧力に昇圧し, 粒子捕集実験を開始した.なお大気プラズ マ溶射において, 基材設置相当位置での飛行中溶射粒子の 速度および温度をDPV - 2000 システム (カナダ・TECNAR 社製）により，その場計測した。

\section{3. 溶射粒子偏平挙動における 特徵的変化}

平滑固体表面に衝突した粒子の偏平挙動は, 現象を単純 化した理論解析により粒子偏平率と粒子飛行情報との関 係として記述される，すなわち，偏平完了時の円盤直径： $\mathrm{D}$ に対する飛来した球状粒子原直径： $\mathrm{d}$ の比として偏平率： $\xi=\mathrm{D} / \mathrm{d}$ が定義され, Jones ${ }^{1)}$ または Madejski モデル 2)に おいて, 偏平に対し凝固の影響が無視できる場合に $\xi$ は, レイノルズ数 $: \operatorname{Re}=\rho \mathrm{vd} / \eta$ の関数として,

$$
\xi=\mathrm{A} \cdot \mathrm{Re}^{\mathrm{B}} \text {. }
$$

と表される。ここに $\rho$ : 粒子の密度, $\mathrm{v}$ : 粒子の飛行速度, $\rho$ : 粒子の粘性係数, A, B : 係数である. 式 (1)は, 粒子 偏平度合いが粒子の有する速度, ならびに粒子の粘性に支 配されることを示している。ここで粘性は温度に強く依存 することから，換言すれば式 (1)は，溶射粒子偏平度合い が, 飛行中粒子の速度および温度により制御可能なことを
教えている. 昨今では溶射プロセスの制御法として, 飛行 粒子の温度, 速度をその場計測し, 得られたデー夕を フィードバックする手法が取られるが, 上式がその妥当性 を与えている。

上述の Madejski の理論式を筆頭に，これまで多くの偏 平率推定式が提案され，また実験值との照合などにより, その妥当性が吟味されてきた ${ }^{3)}$ ～8). 確かに, 溶融した球 状粒子が衝突後理想的な円盤形状として偏平する限り, こ のような偏平率の推定・評価は, 偏平機構解明の上からも 学術的に重要な検討対象となる.ただし, 偏平率の推定そ のものが実用上いかなる意味を持つのか, その意義を見出 しにくいのも事実である。これに関連し, 大気プラズマ溶 射において, プロセス主因子であるアーク電流值, 作動ガ ス流量ならびに溶射距離の変化に伴う平均粒子速度およ び温度の変化特性がDPV - 2000 システムにより調査され た．得られた結果の一例を Fig.1に示す. 図より，通常の 溶射におけるプロセス諸因子の常識的な範囲内での変化 に対し, 粒子速度および温度の変化は予想される程には大 きくない.したがって，これら粒子飛行情報による偏平形 態の制御そのものが実質上どれほどの意味を持つのかは, より詳細な吟味を要する.

むしろこのような粒子帰属因子に代えて, 基材温度ある いは雾囲気圧力などの粒子/基材界面帰属因子の粒子偏平 に及ぼす影響の大きさを筆者は指摘してきた ${ }^{9)}$.一例とし て Fig.2 に, 基材温度変化に伴う粒子偏平形態変化の様相 を示す. 図に示すように基材温度, より正確には粒子堆積 の温度場を変化させた場合に偏平形態がスプラッシュ状 から円盤状へと激変する.すなわち, 現実の溶射粒子偏平 形態は必ずしも円盤状になるとは限らず, スプラッシュ発 生を伴うなど, より複雑な様相を呈する場合が少なくな い. しかもこの場合, 極めて狭い温度範囲において急峻に 遷移的に変化する特徵的な変化挙動が見出されている。し たがって, スプラッシュ状偏平を含む粒子偏平現象の全容 を把握し, その実像解明によるプロセス制御化が, 実用的 


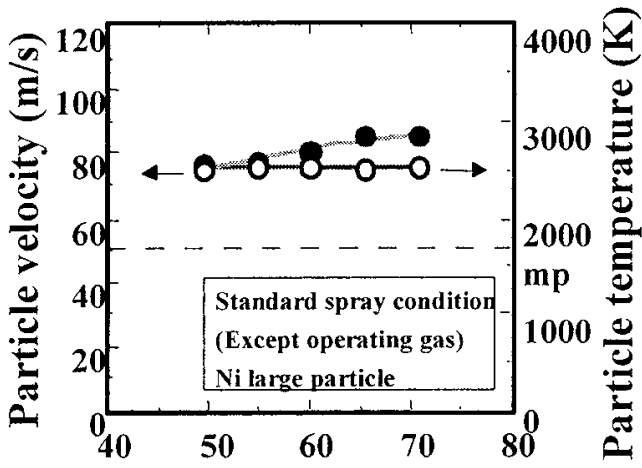

Operating gas flow rate $(\mathrm{l} / \mathrm{min})$

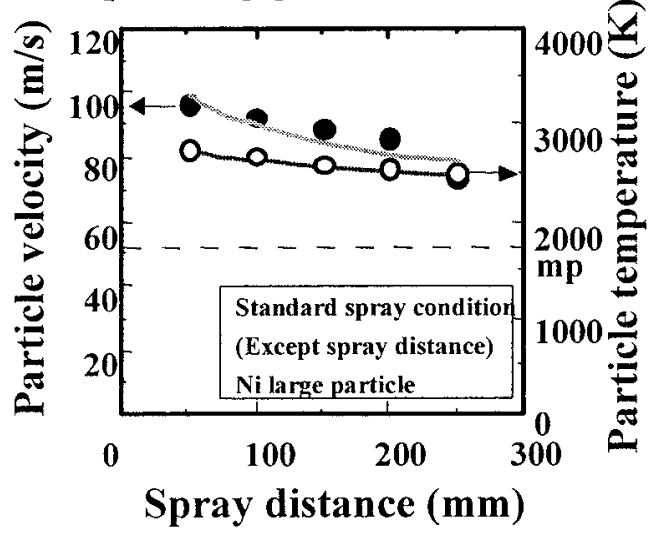

Fig.1. Effect of spray parameters on in-flight conditions of $\mathrm{Ni}$ particles.

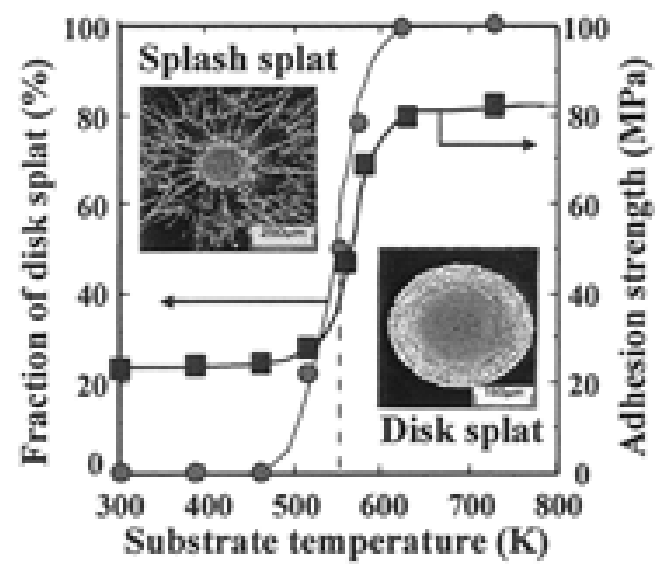

Fig.2. Relation between fraction of disk splat, coating adhesion strength and substrate temperature.
にも意味があるものと考える。

種々の溶射粒子 / 基材の組合せにおいて, 円盤状スプ ラット発生割合の基材予熱温度依存性が系統調査された。 その結果, 多くの金属材料掞よびセラミックス材料粒子に おいて, 基材温度の上昇に伴い粒子偏平形態がスプラッ シュ状から円盤状へと急峻に遷移的に変化する，いわゆる 遷移現象が認められている. 基材温度におけるこのような 臨界温度は “遷移温度：Tt” と定義・呼称され ${ }^{9)}$, SUS304 鋼基材上での実測值の一例を Table 2 に示すように, 遷移 温度は粒子材質より異なる值を示す.さらに興味深いのは Fig.2 に併示するように，ブラスト処理により粗面化した 基材上に形成した皮膜密着強度も基材予熱温度の上昇に 伴い遷移的に向上し，この遷移する温度と，鏡面仕上げし た基材上における一個の粒子における偏平形態遷移温度 とが，定性的によく対応する10) 事実である．皮膜密着強 度と偏平形態との間に緊密な対応関係が存在することは, 基材温度の上昇に伴う粒子偏平形態の変化挙動を調査す ることで, 良好な密着強度を有する皮膜を得るための適正 予熱温度が推定可能なことを意味し，実用上有益である.

ここに, 遷移温度の実用上の有益性を具体事例として示 す. Fig.3に $\mathrm{Ni}^{-} \mathrm{Al}$ および $\mathrm{Ni}^{-} \mathrm{Cr}$ 系溶射粒子の遷移温度を

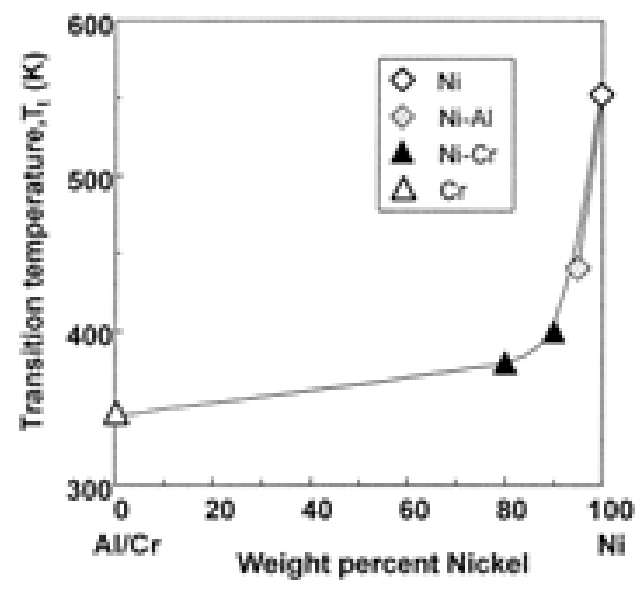

Fig.3. Relation between transition temperature and chemical composition of $\mathrm{Ni}-\mathrm{Al}$ and $\mathrm{Ni}-\mathrm{Cr}$ powders.

Table 2. Transition temperatures.

\begin{tabular}{c|c|c}
\hline Powder material & Spraying device & Transition temperature(K) \\
\hline $\mathrm{Ni}$ & APS & 610 \\
$\mathrm{Mo}$ & $\prime$ & 474 \\
$\mathrm{Cu}$ & $"$ & 394 \\
$\mathrm{Cr}$ & $\prime$ & 387 \\
$\mathrm{Cu}-30 \mathrm{Zn}$ & $\prime$ & 505 \\
\hline $\mathrm{Al}_{2} \mathrm{O}_{3}$ & APS & 318 \\
$\mathrm{TiO}_{2}$ & $"$ & 350 \\
$\mathrm{YSZ}$ & $"$ & 345 \\
\hline
\end{tabular}


粉末組成との関係で整理した結果を示す，罒に示すよう に, 純 $\mathrm{Ni}$ は約 $550 \mathrm{~K}$ の遷移温度を示し, 純 $\mathrm{Ni}$ 皮膜におい て高い密着強度を得るには, 同温度にまで基材を予熱する 必要がある。これに対し，5\% $\mathrm{Al}$ あるいは 10, 20\% Cr を添 加した $\mathrm{Ni}^{-} \mathrm{Al}, \mathrm{Ni}-\mathrm{Cr}$ 粒子のそれは, ともに純 $\mathrm{Ni} に$ に比べる と約 $100 \mathrm{~K}$ 以上低い值を示す。すなわち， $\mathrm{Ni}^{-} \mathrm{Al}$ あるいは $\mathrm{Ni}^{-} \mathrm{Cr}$ をアンダーコート材とすることで, 高い密着強度を 得るために必要な基材予熱温度をそれだけ低く抑えるこ とが可能になる．実用上，アンダーコート材に純 $\mathrm{Ni}$ が使 われることはなく, これにわずかの $\mathrm{Al}$ あるいは $\mathrm{Cr}$ を添加 した Ni-5Al，Ni-10，20Cr，また，より高級な材料として NiCrAlY, NiCoCrAlY な゙が用いられる。その理由として 材料学的に, これら元素の添加による自己発熱効果の発現 などが指摘されるが, その機構の詳細はさておき, 現象的 には, $\mathrm{Al}$ や $\mathrm{Cr}$ 元素の添加が, 高い密着強度を与える基材 予熱温度における臨界值, すなわち遷移温度を $100 \mathrm{~K}$ 以上 も低くする効果にあるものと理解される.材料設計におい て，このことを見越しこれら元素が添加されたとは考えに くいが, ともあれ結果的にそういう恩恵に浴していたもの と理解され，またこの事実は，ここで定義した遷移温度な る指標の導入によって初めて明らかにされたものである.

今後は, 種々の基材／粒子の組合せに関する遷移温度 データベースを構築すること，また遷移温度と基材・粒子 物性などとの間に存在する普遍ルールの解明により，任意 の基材/粒子組合せに対する遷移温度推定法を確立するこ となどが実用上の重要課題である.

\section{4. 粒子偏平機構解明への取組}

一方学術的には, 粒子偏平現象支配因子の特定ならびに 偏平機構の解明, とりわけ遷移温度において偏平形態の急 変する機構解明が重要である.上述のように凝固の起こり やすい室温基材上においてスプラッシュ発生が認められる 事実から，まずはスプラッシュ発生への凝固の影響解明が なされている.種々の金属材料粒子における偏平形態遷移 現象が系統調査された結果, 1) スプラッシュ状偏平では衝 突中心に小円盤が形成され, その周囲にスプラッシュが形 成される,2) 円盤状粒子の裏面が緻密な平滑組織であるの に対し, スプラッシュ状偏平粒子の裏面は多孔質な凝固組 織を呈する,3) 基材衝突の直後に粒子底部には初期急速凝 固層が形成される,4) スプラッシュは急速凝固小円盤の形 成による液滴の周囲への飛散であり, 初期凝固がスプラッ シュ発生の一因と考えられる, などの諸点が示された ${ }^{9)}$. このような遷移現象が, 筆者により国際溶射会議で公表さ れた ${ }^{11)}$ のを契機に，この問題への取組が散見されるよう
になった. 典型例として, 数值解析の立場からとりくんで いる Mostaghimiらの最新の成果では, Fig.4に示すように, 衝突後 $1 \mu \mathrm{s}$ 近傍において円盤状偏平粒子外周部の流れに 不均一性が認められ, これがスプラッシュへと結びっくこ と, 同時刻において認められる基材接触部粒子裏面での初 期凝固層の形成が, その上に存在する粒子内溶融部の急速 流れをもたらし, スプラッシュを誘発するとの機構が指摘 されている12).

この結果を受け筆者らは, 上述の知見の真偽を検証する ために, セラミックス溶射粒子の偏平挙動を調査した. こ のため Fig.5 に示すように，破線を境に金蒸着した面と， むき出しの面を有するステンレス鋼基材を準備し, 当該基 材表面上にアルミナ粒子を溶射し, 偏平挙動を観察した. ここに金蒸着面, およびむき出し面上でのアルミナ粒子の

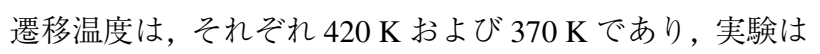
その間の $400 \mathrm{~K}$ で行われた. その結果，両面の境目となる 破線にまたがって衝突した粒子では，金蒸着面上でスプ ラッシュが発生したのに対し, むき出し面上で円盤状とな る予想どおりの偏平挙動が観察された。ここで問題は, ス プラッシュ状偏平粒子の衝突中心における初期凝固層存 在の有無にあり, 観察の結果, 衝突中心での初期凝固の形 成を伴わずにスプラッシュ発生が可能であること ${ }^{13)}$ が分

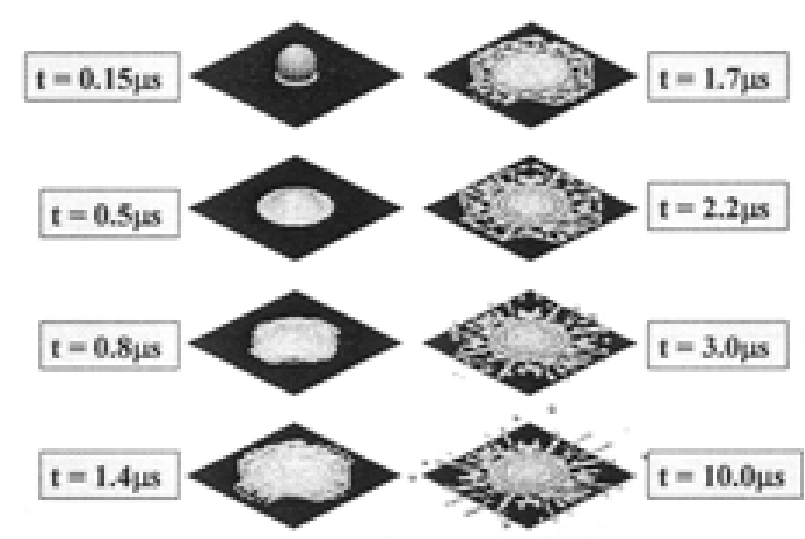

Fig.4. Simulation result showing impact of $\mathrm{Ni}$ particle onto SUS304 substrate.

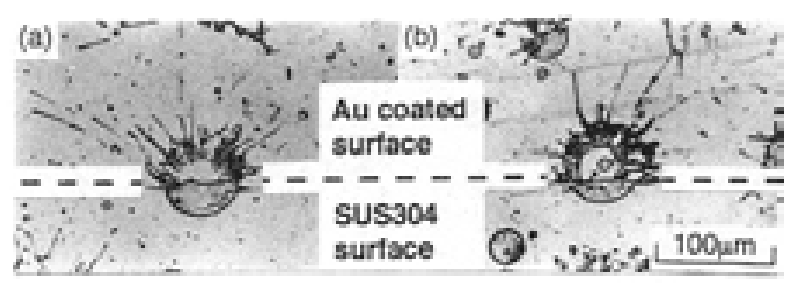

Fig.5. $\mathrm{Al}_{2} \mathrm{O}_{3}$ splat morphologies onto SUS304 substrate at $400 \mathrm{~K}$. 
かった。このことは，スプラッシュ発生に対し初期凝固が 必ずしも関与しないことを示している。

近年 Sampath らは, 基材温度の上昇に伴う偏平形態遷移 の主因が, 基材表面吸着物質の脱離によると推察している 14)。すなわち基材温度が低い場合, 基材表面にはガス吸着 層が存在し, 溶射粒子／基材界面でのガス種の蒸発による 急激な体積膨張がスプラッシュ発生を誘起する一方, 基材 加熱に伴うガス種の脱離により，高温基材上で粒子は良好 な接触状態の下に円盤状偏平形態となる。この見解は，あ る狭い温度範囲で急峻に起こる偏平形態の遷移的な变化 を巧みに説明するものとして注目される。

ただし，スプラッシュ発生を力学的観点から捉えると， 水滴の固体表面への衝突のように, 液滴の相変化を伴わな い現象においては一般に, 粒子の有する $K$ 值（一般に Sommerfeld 数と呼称される $): K=\left(W e \cdot R e^{0.5}\right)^{0.5}$ が, 臨界 值である $K=57.7$ に達した場合に，水滴は液膜破壊を伴 う偏平挙動を起こすことが知られている ${ }^{15)}$.すなわち, ス プラッシュ状偏平形態となる。これを受け, 各種金属材料 溶射粒子について, 実測された粒子飛行情報を基に物性に 温度依存データを用いるなど可能な限り正確な $K$ 值が見 積られた結果，Fig.6に示すように，通常の溶射粒子では $K=200 \sim 1000$ 程度の大きな值を示し, スプラッシュ発生 に十分な駆動力を有する液滴であることが判明している ${ }^{16)}$.

この事実は, 粒子偏平形態遷移問題の本質が, 上述した 粒子／基材界面吸着物質介在の可能性に象徵されるよう な, 基材温度の低い場合になぜスプラッシュが発生するの かを問うスプラッシュ発生機構の解明にではなく, 遷移温 度 $\mathrm{Tt}$ を超える基材温度において，過分な駆動力を有する

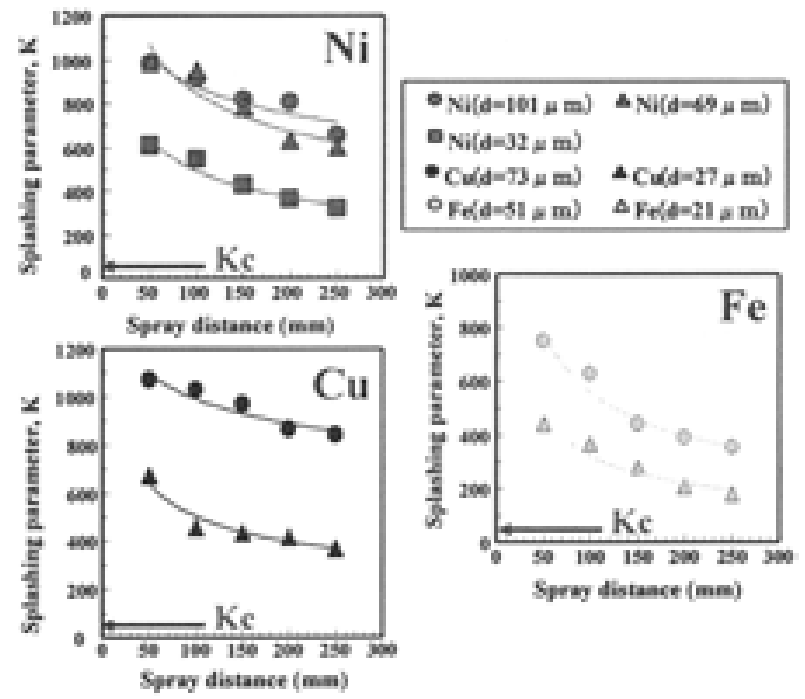

Fig.6. Measurement results of splashing parameter, $\mathrm{K}$ of regular thermal sprayed particles.
粒子の衝突にもかかわらず，なぜ，どのようにしてスプ ラッシュ発生が抑制され, 円盤状偏平形態が現れるのか? その機構解明にこそあることを教えている.すなわち基材 加熱条件において, 円盤状偏平形態をもたらす機構こそが 解明されなければならない。

その後引き続き, 以上のような粒子堆積温度場の影響解 明に加え, 減圧プラズマ溶射装置を用い, 種々の金属材料 における雾囲気圧力と室温基材上での偏平形態との関係 が系統調査されている，その結果 Fig.7に示すように，多
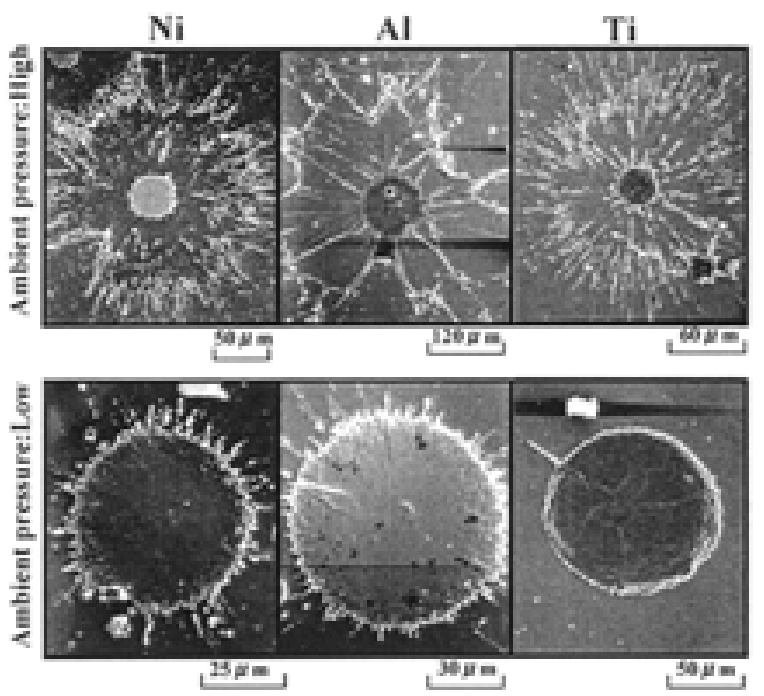

Fig.7. Splat morphologies of metallic particles at different ambient pressures.
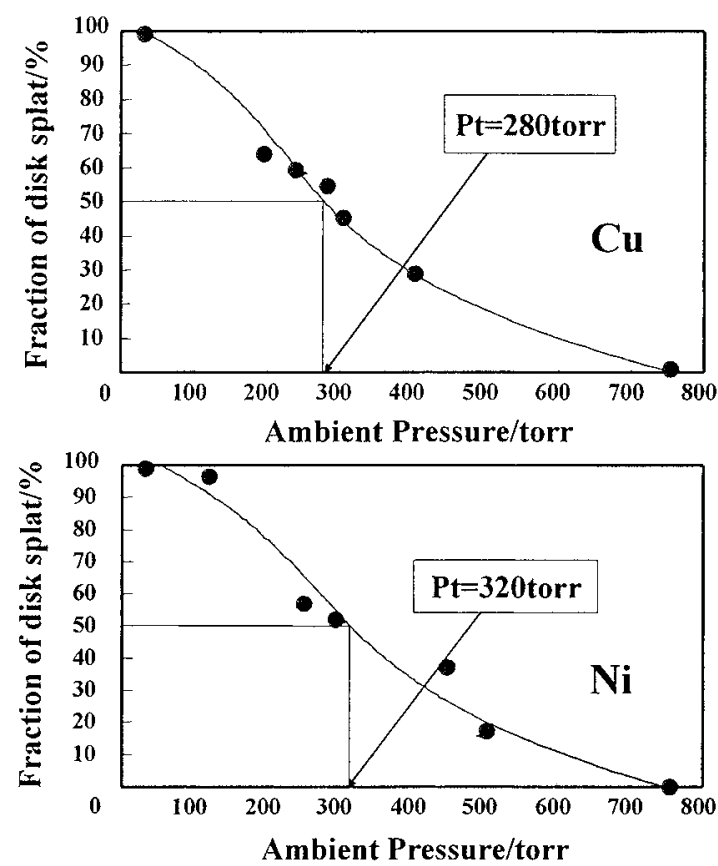

Fig.8. Fraction of disk splat at different pressure on SUS304 substrate. 
くの金属材料溶射粒子において雲囲気圧力の低下に従い, 偏平形態がスプラッシュ状から円盤状へと遷移する傾向 が認められた.この傾向を多くの材料粒子に対し定量評価 した結果，Fig.8に示すように雲囲気圧力の变化に伴い偏 平形態が遷移的に変化する圧力（遷移圧力：Pt と呼称）が 存在すること, 同一基材の場合に Pt 值は粒子材料によっ て異なること, などの諸点が明らかにされた ${ }^{17)}$. ただし， この場合, 基材温度は室温に固定されていることから，こ こでの偏平形態遷移は温度変化とは無関係であり, 雲囲気 ガス分率または基材表面吸着ガスなど, 粒子 / 基材界面物 質の介在によることが示唆される.

\section{5. 遷移マップとしてのプロセス 制御への提案}

以上の系統デー夕を基に, SUS304 鋼基材上での各種材 料粒子の遷移温度 $\mathrm{Tt}$ および遷移圧力 $\mathrm{Pt}$ をつにまとめた 結果を Fig.9 に示す.基材温度を室温とする Pt 值の材質依 存性には, 多少の例外は除くとして，より活性な金属ほど 高い遷移圧力を持つ傾向が見て取れる. 一方, 大気压下で 得た $\mathrm{Tt}$ 值の材質依存性も, ほぼ同じような傾向を示すこ とが分かる ${ }^{17)}$. さらに雲囲気圧力減少に伴う粒子裏面組 織構造が, 基材温度の変化の場合と同様に, 多孔質組織か ら緻密組織へと変化する傾向が認められた観察結果より, 溶射粒子偏平形態に対する堆積温度場および雲囲気圧力 双方の影響に等価性が示唆される。したがって, 溶射粒子 偏平形態, 還元すれば作成される皮膜特性に対する両因子 の影響は 3 次元的な概念図として Fig.10のように整理さ れ, 両因子における臨界值としての遷移点を基準とし, 任 意の堆積温度場および雲囲気圧力の組合せの選択により， 所望とする皮膜特性が得られる可能性が示唆される.この ことを裏付ける具体例として, 種々の金属材料溶射粒子に

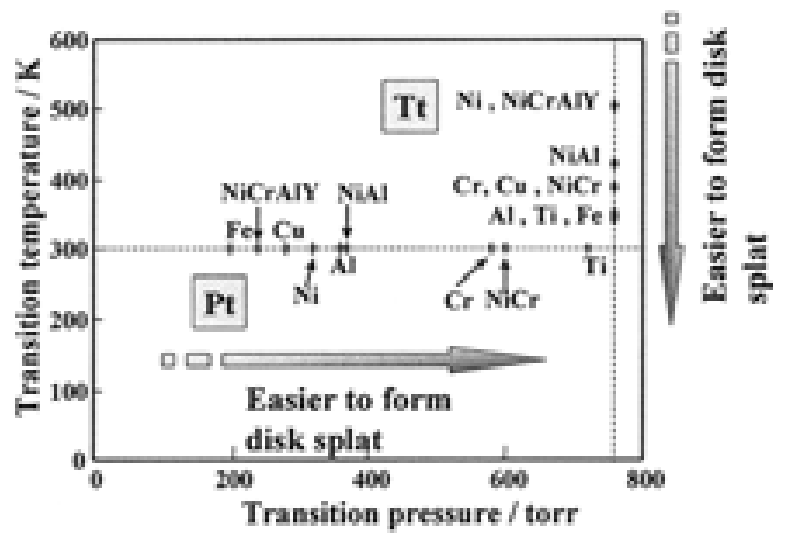

Fig.9. Transition temperature and transition pressure in each thermal sprayed particle.
おいて実測された 3 次元遷移曲面を一例としてFig.11に示す. 他の材料粒子においても同様の曲面データが逐次集積さ れつつあり, 今後は当該データベースの構築が課題である. ともあれ, 本 3 次元遷移曲面は, 溶射皮膜の各種特性制御 に対する効果的な制御指針として実用的に有用である.

最後に,このような両遷移点において偏平現象が急変す る機構の解明が必要である. 遷移圧力の場合には基材温度 が室温であることから, 粒子／基材界面帰属因子としての 基材表面への吸着物あるいは界面に物理的に巻き込まれ るガスの影響である公算が高い.ただし，遷移温度におけ る遷移が, 同じく粒子／基材界面吸着物またはガスの介在 により支配されるのか否かは，現時点では断定できない. これへの考察を付す上で興味深い観察事実を以下に示す.

一つは, Fig.3 に示した $\mathrm{Ni}^{-} \mathrm{Cr}$ 粒子に関する微視組織観

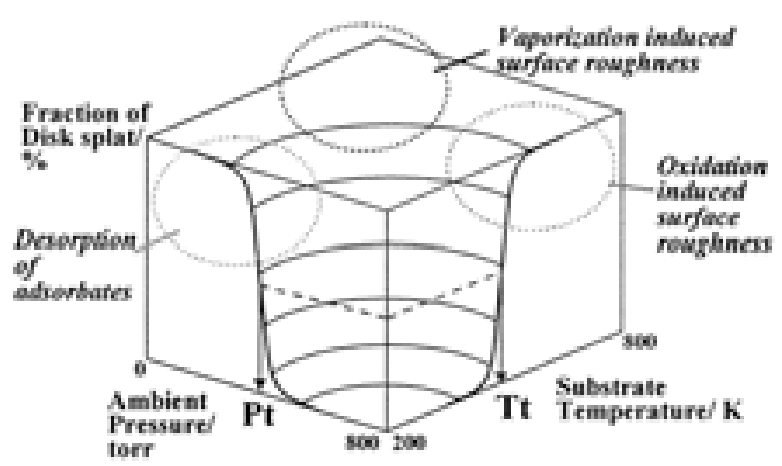

Fig.10. 3-D transition mapping in thermal spray process.

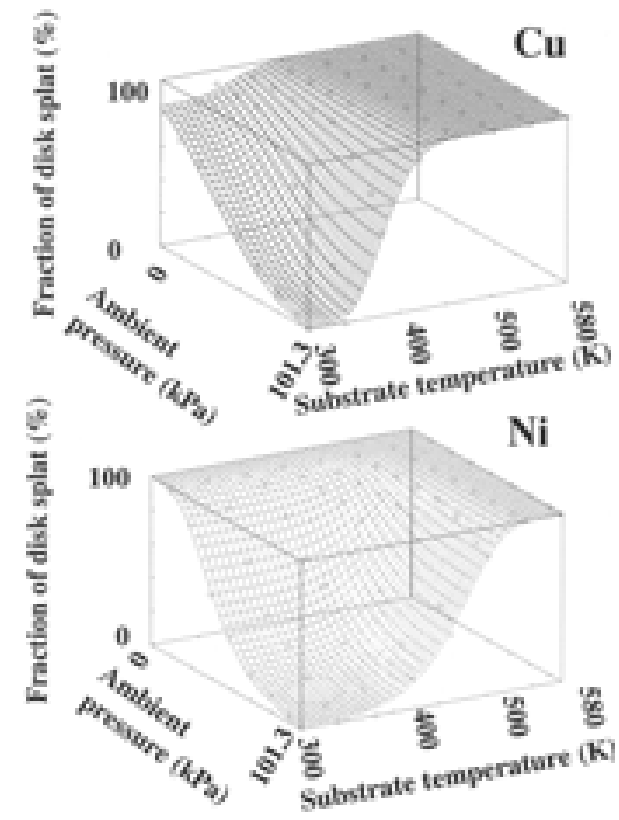

Fig.11. Transition curvatures for each sprayed material. 
察結果である. Fig.12 上段に $\mathrm{Ni}^{-} \mathrm{Cr}$ 原材料粉末の断面組織 を示すが， $\mathrm{Ni}, \mathrm{Cr}$ 両元素は粉末内に均一に分布する。こ れを大気プラズマ溶射した後の粒子断面組織を同図下段 に示す。これより粒子表面には，活性な $\mathrm{Cr}$ 元素の濃化現 象が認められる。大気中の酸素との結合を求め $\mathrm{Cr}$ 元素が 表面へと拡散した結果である。すなわち, 通常大気中プラ ズマ溶射では， $\mathrm{NiCr}$ 粒子は表層を $\mathrm{Cr}$ 酸化物に覆われた状 態で飛来し，付着する．このような粒子が基材表面に付着 した後の偏平粒子の縦断面組織を Fig.13に示す. 図上段 には基材温度が室温の場合のスプラッシュ状粒子の，また 下段には, 加熱基材上での円盤状粒子の縦断面組織をそれ ぞれ示す。これより，両粒子において $\mathrm{Ni}$ 元素の粒子厚さ 方向での分布状態に顕著な相違は認められない.これに対 し，室温基材上の粒子においては，粒子表面に $\mathrm{Cr}$ が濃化 するのに対し，加熱基材上の粒子では基材／界面に $\mathrm{Cr}$ 濃 化層が存在する顕著な相違が認められた。Cr 濃化層の優
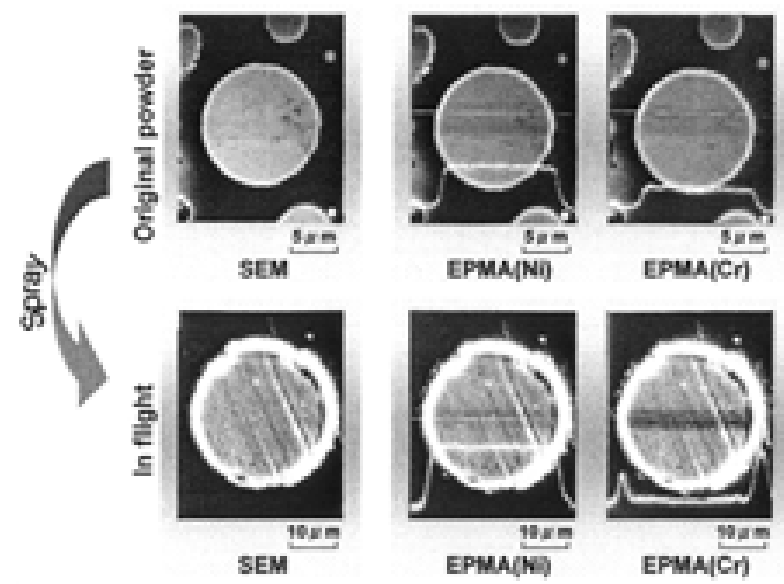

Fig.12. Cross-section microstructures of $\mathrm{Ni}-20 \mathrm{Cr}$ particle.

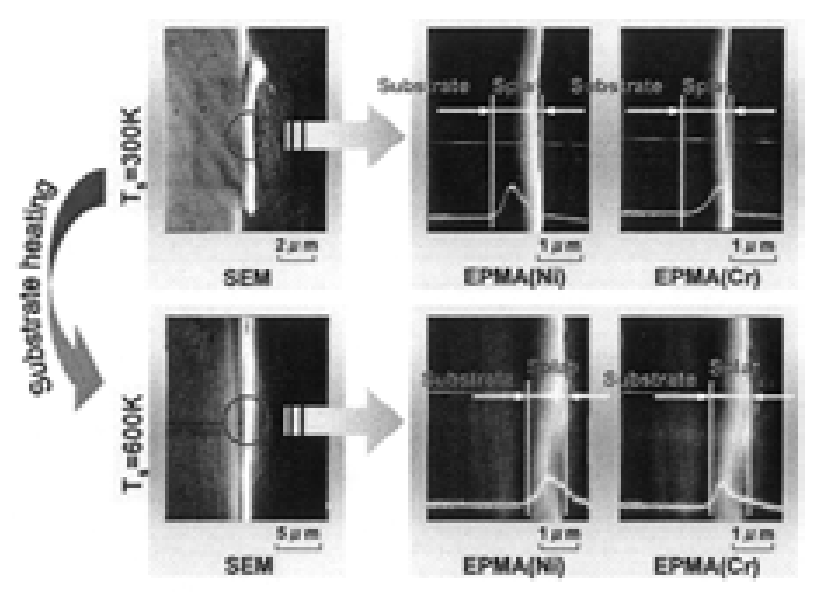

Fig.13. Cross-section microstructures of $\mathrm{Ni}-20 \mathrm{Cr}$ splat on SUS304 substrate. Ts: substrate temperature.
先的な存在位置が堆積温度場の違いにより異なる原因が 基材表面吸着物質にあるとは考え難く, むしろ基材／粒子 間のぬれ性に起因すると考えるのが妥当であろう．Fig.3 で述べた, 純 $\mathrm{Ni} へ$ の少量の $\mathrm{Cr}$ 元素の添加が遷移温度の低 下をもたらした理由も, 純 $\mathrm{Ni}$ 粒子に比べ $\mathrm{Ni}^{-} \mathrm{Cr}$ 粒子が表 面 $\mathrm{Cr}$ 酸化物を有する分，基材最表層に存在する酸化物と のぬれ性が良かったためと解釈される.すなわち, 粒子偏 平における主因は, 基本的に粒子／基材間のぬれ性にある ものと考える.

二つ目は, 大気中において一度遷移温度付近にまで加熱 し,これを室温にまで冷却した基材上での粒子偏平形態が 円盤状となる事実である. 加熱冷却に伴う基材の変化とし て具体的には, 吸着物質の脱離吸着および表面酸化の可能 性が高い.ただし冷却後室温において円盤状偏平形態が認 められる事実からは, 加熱状態で円盤状偏平を誘発する機 構が室温にまで残存する,すなわち不可逆変化の関与を示 唆しており, その意味ではこの場合の主因は表面酸化にあ るものと考えられる。これを受け, 表面酸化のぬれ環境変 化への関与の具体像が吟味されている. 基材表面酸化のぬ れ環境変化への影響は, 酸化物形成としての化学的側面と 表面粗さ変化としての物理的側面を伴う.オージェ分析結 果によれば, 通常多くの金属材料基材表面には, 室温での 鏡面研磨状態ですでに酸化物が存在し, 加熱に伴い酸化層 の厚さは増大するものの, 表面組成そのものはほとんど変 化しないことが検証された ${ }^{18)}$. すなわち酸化によるぬれ 環境变化への化学的側面の影響は僅少である。これに対 し, 酸化に伴う表面粗さ変化が原子間力顕微鏡 $(\mathrm{AFM})$ に より実測され，特に Fig.14 に示すように Skewness: Sk 值 の正負の変化が, 円盤状粒子発生によく対応する事実が示 されており, 加熱に伴うナノオーダーでの表面粗さにおけ

(a) Polbhed with 0.3yen aleaina

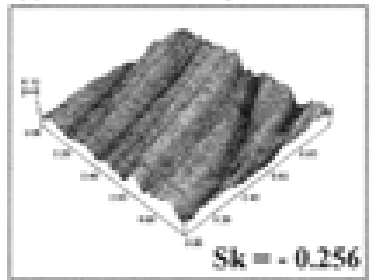

(b) Once beated to 673K of (a)
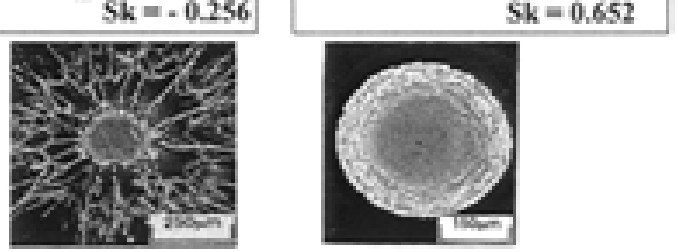

Fig.14. Surface morphologies by AFM, skewness values and splat morphologies on SUS304 substrate of (a) polished with 0.3 $\mu \mathrm{m}$ alumina and (b) once heated to $673 \mathrm{~K}$ of $(\mathrm{a})$. 
る形状的な特徵が, ぬれ変化に効果的に関与する点が指摘 されている ${ }^{19)}$. 基材加熱による円盤状偏平形態の現出が すべてナノオーダーの粗さ特性の変化に起因するとは断 定されないが, 有力な因子の一つとして, 今後さらなる影 響解明が待たれる。

\section{6. おわりに}

CVD, PVD 法を筆頭に, 原子を積層単位とし厚さ数 $\mu \mathrm{m}$ 以下の高品質皮膜を創製する薄膜技術は, 確立された信頼 性, 制御性の下に幅広い応用展開を図るなど, 技術として の完成度が高い. 一方, 数十 $\mu \mathrm{m}$ ほどの大きさの粒子の積 層に基づく溶射法は，いま一つ制御性・再現性に欠け，十 分な信頼性を勝ち得たとはいい難い.ただし近年では, 粉 末調整, 粉末送給および状態計測制御などの各種周辺技術 の高度化にも援護され，溶射技術の制御性も徐々にではあ るが確立しつつある. 通常, 溶射プロセス制御のための主 たる管理対象は衝突直前の飛行粒子の速度および温度と され，飛行情報計測結果をフィードバックする制御技術の 開発が進められている。その延長として, 今後ますます制 御性が向上し, 信頼性ある高品位皮膜が高い再現性の下に 作製される日の到来も，そう遠い話ではないものと思われる.

ただし筆者は，プロセス全体に及ぶ系統調査の中で，速 度, 温度の粒子帰属因子以上に, 粒子／基材界面帰属因子 の影響の大きさを見出し，この方向からのプロセス制御の あり方を追究してきた. 特に, 皮膜の構造や特性を変え, あるいは積極的に制御するには, まず構成単位である 1 個 の粒子の挙動に本質が潜むと考え, 単一粒子の基材上での 振る舞いを系統調査した。本報では，これまでに実施した 筆者らの研究成果の一端を中心に, 当該研究分野における 問題点, 研究の現状, 今後の課題などを概説した. 十分に 語り尽くせたとはいえず，また種々ご批判・ご指摘のある ところとは思われるが, 読者諸賢の一助にでもなれば幸い である。

近年, 微細粉末活用による斬新な膜創製機構を駆使する コールドスプレー法 20), エアロゾルデポジション法21) な どの新規技術が開発され, 粒子積層プロセスにおける新時 代到来が予感される．溶射を含むこれら三つのプロセス は, ともに膜創製の基本単位を数〜数十 $\mu \mathrm{m}$ サイズの粒 子とする点で共通であり, 一見相異なるこれら三つのプロ セスも多くの共通点を有する同族：粒子積層 Particle Deposition, 略して PD 法として, 相互に補完しつつ発展 することが期待される. また粒子積層機構の解明において も, 個々のプロセス固有の範囲は別として, 相互の境界領 域においては類似の付着機構関与の可能性が示唆される
ことから, 今後は, これら総体を厚膜創製分野における基 幹技術として確立していくことが重要である.

\section{(文 献)}

1) 柴田浩幸, 早稲田嘉夫, 福本昌宏, 西林景仁, 若林 栄, 太田弘道, 友田 陽:高温学会誌, 20(1994), 35.

2) J. Madejski:Int. J. Heat Mass Transfer, 19 (1976), 1009.

3) 西岡映二, 福本昌宏: 溶接学会論文集, 16 (1998), 437.

4) T.Watanabe, I.Kuribayashi, T.Honda, A.Kanzawa:Chem. Engg. Sci., 47(1992), 3059.

5) H.Fukanuma, A.Ohmori:Proc. of NTSC' 94 (1994), 563.

6) 天田重庚, 春山昌広, 大谷木貴司:日本金属学会誌, 63 (1999), 103.

7) V.V.Sobolev, J.M.Guilemany, A.J.Martin:J. Thermal Spray Tech., 5(1996), 207.

8) 平田好則, 小澤拓生, 濱口 晶, 黄地尚義:溶接学会講演 概要, 63(1998), 58.

9) 福本昌宏, 加藤信一郎, 大渡智喜, 黄 亜輝: 日本金属学 会誌, 59(1995), 1178.

10) 福本昌宏, 横山 剛, 奥 一也, 田中康徳: 高温学会誌, 23-Supplement (1997), 240.

11) M. Fukumoto, S. Kato and I. Okane, Proc. of Int. Thermal Spray Conf.'95, 1(1995), 353.

12) M.Pasndideh-Fard, V.Pershin, S.Chandra, J.Mostaghimi:J. of Thermal Spray Tech., 11 (2002), 206.

13）田中康徳, 福本昌宏: 溶接学会論文集, 17(1999), 259.

14) X.Jiang, Y.Wan, H.Herman, S.Sampath:Thin Solid Films, 385 (2001), 132.

15) C.Mundo, M.Sommerfeld, C.Tropea:Int. J. Multiphase Flow, 21(1995), 151.

16) M.Fukumoto, E.Nishioka, T.Nishiyama:Proc. of ITSC'01, (2001), 841.

17) 福本昌宏, 安井利明, 鍛示浩史, 椎葉昌洋: 日本溶射協 会第75回講演大会講演論文集，(2002), 49.

18) M.Fukumoto, T.Nishiyama, E.Nishioka:Proc. of ITSC'02, (2002), 37.

19) M. Fukumoto, I. Ohgitani, T. Yasui:Materials Transactions, 45 (2004), 1869.

20) T. Schmidt, F. Gartner, T. Stoltenhoff, H. Kreye, H. Assadi, Proc. ITSC-2005, (2005), CD.

21) 明渡 純, 微粒子·超微粒子ビームによるナノクリス タル膜の形成, 粉体と工業, 34(2002), 48. 